Radmila Pidlypna. Implementation of government programs of social risk management. Економічний дискурс. 2020. Випуск 3. С. 38-44.

DOI: https://doi.org/10.36742/2410-0919-2020-3-4

УДК 364.65:35 (477)

JEL Classification: H51, H53, 138, J28

\author{
Radmila Pidlypna \\ Doctor of Economics, Professor \\ Department of Accounting and Taxation, \\ Uzhgorod Trade and Economic Institute of Kyiv National University \\ of Trade and Economics Uzhhorod, Ukraine \\ E-mail: radmila2008@ukr.net \\ ORCID: 0000-0001-6886-5834
}

\title{
IMPLEMENTATION OF GOVERNMENT PROGRAMS OF SOCIAL RISK MANAGEMENT
}

\begin{abstract}
Introduction. Accelerated pace of development of society contributes to the accelerated generation of social risks, modern society is characterized by constant technological, natural, economic, environmental, socio-cultural changes. Therefore, minimizing social risks and leveling their consequences is of paramount importance.

Methods. Diagnosis of the state of the social risk management system combined the principles of systemic, structuralfunctional and targeted analysis, which provided a comprehensive assessment of the whole and individual components.

Results. The analysis of expenditures on the social sphere showed their stable absolute growth despite the dynamic reduction of their share in the budget. Social risks are largely due to the non-transparency of the mechanism for regulating the supply and demand of labor in the domestic labor market. A significant share of macroeconomic social risks is related to the problems of social infrastructure, which is financed from the budget. Problems with access to health care, the opacity of the pharmaceutical market, the degradation of the health care network, chronic underfunding, and the lack of health insurance also generate social risks. The task of state policy should be to prevent and prevent social risks, identify social conflicts that lead to destructive consequences. Systematization of social risks allows to methodologically substantiate the mechanisms of social risk management, to modernize the models of social protection of the population, to develop effective tools for ensuring public management of social risks.

Discussion. The impossibility of reducing funding for social needs without deteriorating the quality of life and social protection of the population requires further search for alternative sources of funding for socio-cultural expenditures, rationalization in the budget structure to effectively combat the development of social risks.
\end{abstract}

Keywords: social policy, social risks, social transfers, household expenditures, labor market, health care.

\section{Introduction.}

The imperfection of the domestic system of social protection, a certain amorphousness of social policy, caused by inconsistencies between social and economic policy of the state, their tasks and goals, weaken the social development of Ukraine, lead to social risks. In conditions of unstable domestic economic situation, exacerbated by the negative impact of global financial, economic and social crises, external military, political and economic aggression, as well as new social challenges caused by the negative impact of the rapid spread of the Covid-19 pandemic, rising risks of income, as a consequence, leads to financial difficulties and impoverishment of the population.

Accelerated rates of development contribute to the accelerated generation of risks, which become 
an everyday, but often quite unpredictable phenomenon, so it is of paramount importance if not to eliminate, then at least minimize risks and mitigate their consequences, ie security. In particular, the population is growing, whose resources are very limited and do not allow to maintain an acceptable standard of living in society. Thus, the issue of protection of citizens from these risks is becoming increasingly important.

\section{Analysis of recent research and publications.}

Examining the semantics of social risk, it is advisable to pay attention to the statutory definition of risk as a circumstance "as a result of which citizens and / or their families may temporarily or permanently lose their livelihood and need material support or social services under compulsory state social insurance" [8]. O. Pilipenko proposed a similar definition, describing social risk as a socially significant circumstance of an objective nature, with the onset of which citizens are unable to support themselves, and therefore need additional material protection from the state [6].

The objectivity of the existence of social risk is also emphasized by Yu. Khomych, who notes that social risk is a real threat of material and moral damage, which destroys the stability of life and the relative well-being of the population [9]. V. Nadraha clarifies that social risk is a socially significant circumstance of an objective nature enshrined in law and recognized by society, and citizens cannot independently avoid this circumstance [4]. Mazzoleni et al. show in their study that societal challenges, risks and priorities around the world are changing due to the constraints imposed by national governments to curb the diffusion of the SARS-CoV-2 (Covid-19) pandemic [11].

Although it is not possible to draw definitive sound conclusions on how to effectively address new social risks, the scientific community has a moral obligation to ask questions and try to provide an interdisciplinary analysis and perspective based on socio-economic, organizational and ethical challenges arising from emergencies.

According to $U$. Beck's theory, modern society is at risk of constant technological, natural, economic, environmental, socio-cultural changes [10]. Thus, scientists have laid the foundations for the formation of a new approach to the universalization of modern social risks that threaten society as a whole, extending its influence to all institutions of society.

\section{The purpose.}

The main task of the article is to identify priority areas for the development of social risk management mechanisms.

\section{Research methodology.}

Diagnosis of the state of the social risk management system combined the principles of systemic, structural-functional and targeted analysis, which provided a comprehensive assessment of the whole and individual components. The application of a systematic approach allowed to analyze the consistency of the social risk management system with the macroeconomic environment in conditions of social instability.

\section{Results.}

The main prerequisite for the emergence of social risks is the inconsistency and inconsistency between social and economic policies. In general, the social sphere in Ukraine is characterized by a confusing and non-transparent system of providing social benefits, which does not contribute to the effective redistribution of resources to provide assistance to the poorest sections of the population. Counteraction to social risks as a determining basis for the realization of social needs of the population of Ukraine is based on a set of constitutionally enshrined guarantees and opportunities [6].

Guarantees of social support ensure the constitutional rights of citizens in the social sphere, determine social norms in real life, but only the minimum limits of social security are enshrined in law. In particular, a number of social benefits are specified annually in the planning of the state budget (Table 1). 
The above statistical information indicates a stable absolute growth of expenditures in the social sphere, but their share during 2014-2019 decreased both in GDP and in the overall structure of budget expenditures.

Table 1. Dynamics of budget expenditures of Ukraine for the social sphere in 2014-2019 (UAH billion)*

\begin{tabular}{|l|c|c|c|c|c|c|c|}
\hline \multicolumn{1}{|c|}{ Indicators } & 2014 & 2015 & 2016 & 2017 & 2018 & 2019 & $2019 / 2014, \%$ \\
\hline Total budget expenditures, incl. & 523,1 & 679,9 & 835,6 & 1056,8 & 1250,2 & 1370,1 & 261,92 \\
\hline $\begin{array}{l}\text { Budget expenditures on social } \\
\text { protection and social security }\end{array}$ & 138,0 & 176,3 & 258,3 & 285,8 & 309,3 & 321,8 & 233,19 \\
\hline $\begin{array}{l}\text { The share of the social sphere in } \\
\text { budget expenditures, } \%\end{array}$ & 63,16 & 58,66 & 60,29 & 59,12 & 56,20 & 55,82 & 88,38 \\
\hline GDP & 1586,9 & 1988,5 & 2383,2 & 2982,9 & 3558,7 & 4080,2 & 257,12 \\
\hline Share of social sphere in GDP, $\%$ & 20,8 & 20,1 & 21,1 & 20,9 & 19,7 & 18,7 & 90,03 \\
\hline
\end{tabular}

*Source: calculated according to [2].

It should be noted that the policy of social protection is integrated into the economy of Ukraine, so the planning of social activities requires a clear identification of funding sources. Prolonged underfunding of the social sphere, covering only current expenditures has led to the actual destruction of social infrastructure, moral and physical depreciation of fixed assets, chronic need for capital expenditures and does not contribute to the quality of social services. The predominance of budget funding and the inconsistency and spontaneity of the introduction of private funding cause an increase in the burden on budgets at different levels, and chronic budget deficits and uncontrolled spending of budget funds determine the financing of this segment on a residual basis.

Risks in the social sphere are largely due to insufficient regulation of the labor market (Table 2).

Table 2. Main indicators of the labor market of Ukraine (for working age) in 2014-2019*

\begin{tabular}{|c|c|c|c|c|c|c|c|c|c|}
\hline \multicolumn{3}{|c|}{ Indicators $\mathrm{n}$} & 2014 & 2015 & 2016 & 2017 & 2018 & 2019 & $\begin{array}{c}2019 / \\
2014, \%\end{array}$ \\
\hline \multirow[t]{2}{*}{ Workforce } & \multicolumn{2}{|c|}{$\begin{array}{l}\text { on average, million } \\
\text { people }\end{array}$} & 19,04 & 17,40 & 17,30 & 17,19 & 17,30 & 17,38 & 91,3 \\
\hline & \multicolumn{2}{|c|}{$\begin{array}{l}\text { in } \% \text { to the corresponding } \\
\text { age group }\end{array}$} & 71,4 & 71,5 & 71,1 & 71,5 & 72,7 & 74,0 & 103,6 \\
\hline \multirow[t]{2}{*}{$\begin{array}{l}\text { Employed } \\
\text { population }\end{array}$} & \multicolumn{2}{|c|}{$\begin{array}{l}\text { on average, million } \\
\text { people }\end{array}$} & 17,19 & 15,74 & 15,63 & 15,50 & 15,72 & 15,89 & 92,4 \\
\hline & \multicolumn{2}{|c|}{$\begin{array}{l}\text { in } \% \text { to the corresponding } \\
\text { age group }\end{array}$} & 64,5 & 64,7 & 64,2 & 64,5 & 66,1 & 67,6 & 104,8 \\
\hline \multirow{3}{*}{$\begin{array}{l}\text { The average } \\
\text { monthly salary }\end{array}$} & \multirow[t]{2}{*}{ nominal } & UAH & 3480 & 4195 & 5183 & 7104 & 8865 & 10497 & 301,6 \\
\hline & & $\begin{array}{l}\text { in } \% \text { to the } \\
\text { subsistence } \\
\text { level }\end{array}$ & 285,7 & 304,4 & 323,9 & 403,2 & 461,5 & 499,4 & 174,8 \\
\hline & \multicolumn{2}{|c|}{ real, in $\%$ to the front rock } & 93,5 & 79,8 & 109,0 & 119,1 & 112,5 & 109,8 & 117,4 \\
\hline \multirow{2}{*}{$\begin{array}{l}\text { Unemployed } \\
\text { population } \\
\text { (according to ILO } \\
\text { methodology) }\end{array}$} & \multicolumn{2}{|c|}{$\begin{array}{l}\text { on average, million } \\
\text { people }\end{array}$} & 1,85 & 1,65 & 1,68 & 1,70 & 1,58 & 1,49 & 80,5 \\
\hline & \multicolumn{2}{|c|}{$\begin{array}{l}\text { in } \% \text { to the corresponding } \\
\text { age group }\end{array}$} & 9,7 & 9,5 & 9,7 & 9,9 & 9,1 & 8,6 & 88,7 \\
\hline
\end{tabular}

${ }^{*}$ Source: calculated according to [1].

Low social awareness of employees and social responsibility of employers often arise in conditions of unfair competition and allow entrepreneurs to make extra profits. The actual lack of relationship between labor productivity and its payment is mostly observed in terms of wages. The loss of correlation between the quality of work and their payment virtually eliminates the incentive effect of wages, does not increase its productivity, does not guarantee innovation and, in fact, removes investment resources of enterprises, organizations and institutions that flow instead into the wage fund. Accordingly, low wages, slow growth and complete or partial concealment from the tax authorities, unwillingness to improve working conditions and increase employee safety occur in regions where there is a surplus of 
labor.

The non-transparency of the mechanism of labor supply and demand in the domestic labor market, as well as the mismatch of licensed training in educational institutions with a real need for them cause chronic shifts and deformation of the labor market, unmet needs in some industries and their significant surplus in others, permanent shortage of specialists in rural areas, in some oblasts and regions and, accordingly, inefficient use of labor potential in general. The irrational structure of citizens' incomes is associated with a significant dependence on the volume of social transfers, which were often not related to the economic activity of their recipients, and, accordingly, does not allow to adjust consumer demand and leads to inflationary incomes.

The development of the Covid-19 pandemic and the introduction of quarantine in Ukraine from the second half of March 2020, according to the NBU, may increase the unemployment rate in the second quarter to $12 \%$ in seasonally adjusted terms, as the number of real vacancies in the first two weeks of quarantine decreased twice [5]. It is expected that the negative impact of quarantine measures on the economy will be strong, albeit short-term, and will manifest itself in such systemic risks as declining external demand, declining business activity, consumption and employment. Increasing government spending to overcome the crisis will reduce the negative impact of the pandemic on socio-economic development. In particular, on April 27, 2020, the Government decided to grant the Unemployment Insurance Fund UAH 1,277 million, and on June 10, 2020, an additional UAH 2,972 million. for the payment of unemployment benefits, because as of early summer, the unemployment rate shows an increase of $78 \%$ compared to 2019 .

A significant share of macroeconomic social risks is related to the problems of social infrastructure, which is financed from the budget. The efficiency of the redistributive potential of social infrastructure at the macro level is demonstrated by the distribution of household incomes generated from budgetary social transfers (Fig. 1).

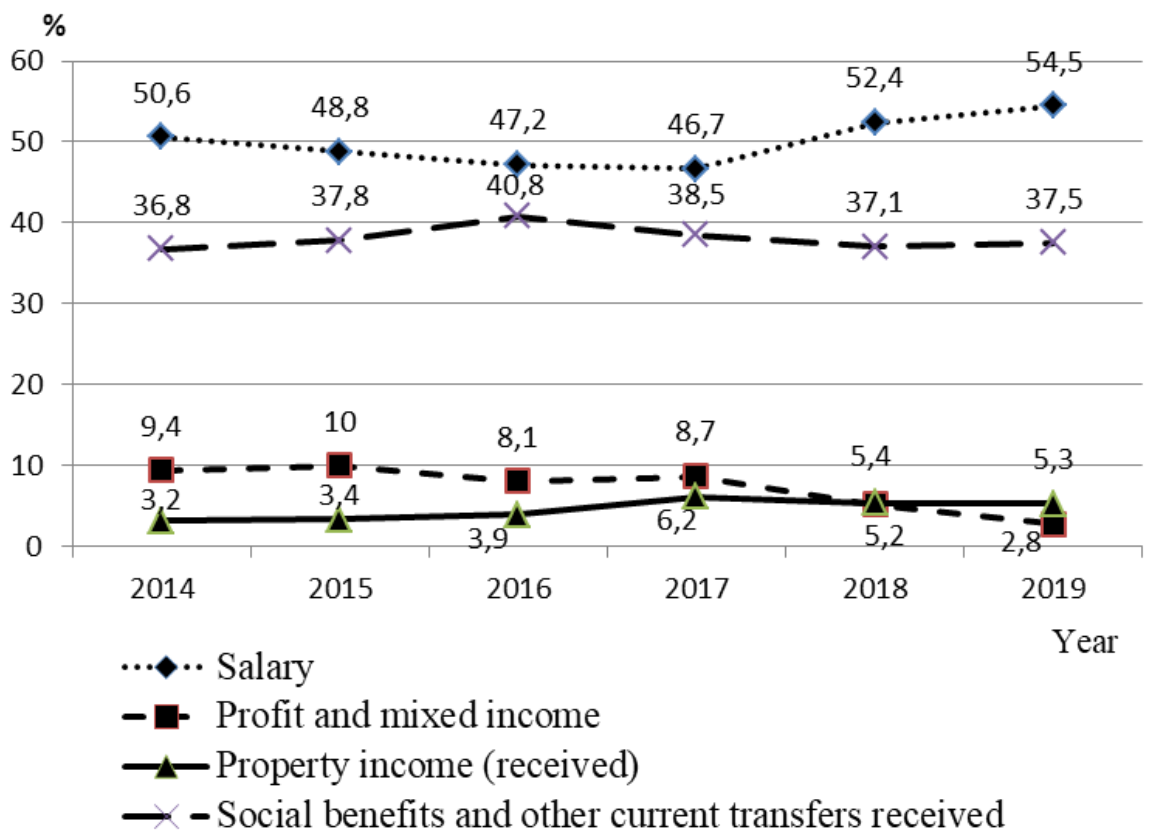

Fig. 1. Structural dynamics of income of the population of Ukraine in 2014-2019* *Source: calculated according to [1]. 
As we can see, despite the fact that the basis of the population's income is a stable salary, the second place in the structure is occupied by social benefits and other received current transfers.

It should also be noted that problems with access to health care, non-transparency of the pharmaceutical market, degradation of the network of health care facilities in rural and remote areas, chronic underfunding of health care costs due to budget deficits, lack of health insurance are also generate social risks. In Ukraine, the idea of compulsory health insurance has become much more important due to the chronic budget deficit and the significant cost of the medical sector [7]. Nevertheless, it should be noted that budget expenditures on health care for 2014-2019 increased from UAH 57.2.6 billion. up to UAH 128.4 billion. (2.2 times), although their share in terms of GDP decreased from $3.6 \%$ to $3.15 \%$. Such funding differs significantly from the usual European practice $(6.7 \%$ in Poland, $7.7 \%$ in the Czech Republic, $10.2 \%$ - on average in the EU) [3].

Accordingly, the share of medical expenditures in 2019 accounted for $73.9 \%$ of current household expenditures (Table 3). At the same time, the distribution of household expenditures on medical services shows that inpatient treatment accounts for only $2.1 \%$ of their total expenditures on medical services, while in the structure of public expenditures this item predominates $(24.9 \%)$.

Table 3. Distribution of costs by types of medical services in 2019 (UAH million)*

\begin{tabular}{|l|c|c|c|c|c|c|}
\hline $\begin{array}{c}\text { Types of medical } \\
\text { services }\end{array}$ & $\begin{array}{c}\text { Types of } \\
\text { medical } \\
\text { services }\end{array}$ & $\begin{array}{c}\text { Types of } \\
\text { medical services }\end{array}$ & $\begin{array}{c}\text { Private } \\
\text { organizations }\end{array}$ & Households & $\begin{array}{c}\text { Other } \\
\text { entities }\end{array}$ & Together \\
\hline $\begin{array}{l}\text { Health care } \\
\text { management }\end{array}$ & 8808,3 & 125,1 & - & - & 343,4 & 9276,8 \\
\hline Inpatient treatment & 32513,3 & 572,7 & 1131 & 8917,2 & - & 43134,2 \\
\hline $\begin{array}{l}\text { Outpatient } \\
\text { treatment }\end{array}$ & 19457,3 & - & 1248 & 17939,9 & 1130,3 & 39775,5 \\
\hline Personal treatment & 6045,3 & 650,7 & 2631,3 & 35440,5 & 1130,3 & 45898,1 \\
\hline Preventive services & 1913,5 & - & - & - & 457,2 & 2370,7 \\
\hline Ancillary services & 3024,3 & - & 252,3 & 8583,4 & - & 11860,0 \\
\hline $\begin{array}{l}\text { The cost of medical } \\
\text { supplies }\end{array}$ & 56638,3 & 1245 & 2631,3 & 333210,4 & 1157,6 & 394882,6 \\
\hline Total & 128400,5 & 2593,5 & 7893,9 & 404091,4 & 4218,8 & 547198,1 \\
\hline
\end{tabular}

*Source: calculated according to [1].

The state budget of Ukraine for 2020 provided for an increase in medical expenditures by $13 \%$ (UAH 145 billion) and planned the introduction of itemized estimates, electronic prescriptions and a transparent mechanism for purchasing services in the medical field. At the same time, the underdevelopment of the mechanism of conversion of savings into investments, the inadequacy of credit mechanisms, the predominance of passive investments over active ones, the predominance of consumer lending lead to social risks of poverty growth. To strengthen the social protection of citizens during the pandemic in 2020, a fund was created to combat its consequences, which allowed to allocate an additional 10 billion UAH. for one-time benefits for more than 10 million people. In addition, the Ministry of Social Policy of Ukraine allocated more than UAH 30 billion. for the payment of social benefits and UAH 98 million. to provide socially vulnerable groups with medical rehabilitation.

Of particular importance in quarantine is the social risk associated with the protection of children's rights, which requires institutional measures of social support for families with children. Due to the cessation of attendance at educational institutions and unplanned return from institutional care, children stay at home around the clock, and therefore, in families in difficult life circumstances, there is an increased risk of failure to meet the needs of quality nutrition, safety, proper care and medical care. Therefore, children's services together with the departments of education and science, health care, centers of relevant social services organize work on:

- analysis of lists of children and identification of families in which there is the greatest risk of inadequate provision of needs and violation of children's rights;

- communication (online, by phone) with the child, his parents, other legal representatives about 
the existing problems in the family, the need for help;

- identification of probable risks to the life and health of the child and assessment of its level of safety;

- social support for the family, including in-kind assistance.

Thus, the successful implementation of state programs of social risk management requires consistent adherence to the following algorithm:

1) qualitative risk analysis (collection, classification, grouping of risks);

2) quantitative assessment of risks (calculation of probabilities of risks, their severity and assessment of consequences);

3) risk minimization (strategy development, selection of the optimal strategy and its implementation);

4) control (monitoring, adjustment of risk assessments, application of tactical measures in case of deviation from the strategy).

\section{Discussions.}

The current social policy in Ukraine in the conditions of socio-economic, ecological and other shocks does not provide balanced preventive management of social risks. The task of public policy should be to prevent and prevent social risks, identify social conflicts that create tension, exacerbate contradictions, increase in scale, become spontaneous, become uncontrollable and lead to destructive consequences. Systematization of social risks allows to carry out methodological substantiation of the mechanism of management of social risks, models of social protection of the population, allows to choose effective tools of maintenance of the state regulation of system of social insurance as a whole.

The impossibility of reducing funding for social needs without deteriorating the quality of life and social protection of the population requires further search for alternative sources of funding for sociocultural expenditures, rationalization in the budget structure to effectively combat the development of social risks.

1. Derzhavna sluzhba statystyky Ukrainy. (2020). Ofitsiinyi web-resurs. Retrieved from http://www.ukrstat.gov.ual.

2. Ministerstvo finansiv Ukrainy. (2020). Vydatky zvedenoho biudzhetu za rokamy. 2014-2019. Retrieved from https://index.minfin.com.ua/ua/finance/budget/cons/expense/2019/.

3. Ministerstvo okhorony zdorovia Ukrainy (2015). Natsionalna stratehiia reformuvannia systemy okhorony zdorovia v Ukraini na period 2015-2020 rokiv. Retrieved from https://moz.gov.ua/uploads/0/691-strategiya.pdf.

4. Nadraha, V. I. (2015). Sotsialni ryzyky v zahalnii teorii ryzykiv: problemy formuvannia poniatiinoho aparatu [Social risks in the general theory of risks: problems of formation of the conceptual apparatus]. Chasopys ekonomichnykh reform [Journal of Economic Reforms], 3, 75-83. [in Ukr.].

5. Natsionalnyi bank Ukrainy. Infliatsiinyi zvit. Kviten 2020 roku. Retrieved from https://bank.gov.ua/admin_uploads/article//R_2020-Q2.pdf?v=4

6. Pylypenko, O. Ye. (2012). Formuvannia prava sotsialnoho zabezpechennia v Ukraini: istorychnyi aspekt [Formation of social security law in Ukraine: historical aspect]. Naukovyi visnyk Akademii munitsypalnoho upravlinnia. Seriia: Upravlinnia [Scientific Bulletin of the Academy of Municipal Administration. Series: Management], 4, 277-283. [in Ukr.].

7. Pidlypna, R. P. (2019). Doslidzhennia systemnoi paradyhmy mekhanizmu derzhavnoho rehuliuvannia sotsialnoho strakhuvannia [Investigation of the systemic paradigm of the mechanism of state regulation of social insurance]. Visnyk Lvivskoho torhovelno-ekonomichnoho universytetu. Seriia: Ekonomichni nauky [Bulletin of Lviv Trade and Economic University. Series: Economic Sciences], 57, 33-38. [in Ukr.].

8. Verkhovna Rada Ukrainy. Pro zahalnooboviazkove derzhavne sotsialne strakhuvannia. Zakon vid 14.01.1998 № 16/98-VR; redaktsiia vid 19.05.2020, pidstava - 587-IX. Retrieved from https://zakon.rada.gov.ua/laws/show/1105-14.

9. Khomych, I. Yu. (2013). Osoblyvosti sotsialnoi dopomohy yak formy sotsialnoho zabezpechennia naselennia Ukrainy [Features of social assistance as a form of social security of the population of Ukraine]. Forum 
prava [Law Forum], 3, 717-724. [in Ukr.].

10. Beck, U. (2014). Risk society. Essential concepts of global environmental governance. Abingdon, UK: Routledge.

11. Mazzoleni, S., Turchetti, G., Ambrosino, N. (2020). The COVID-19 outbreak: From «black swan» to global challenges and opportunities. Pulmonology, 26 (3), 117-118. Retrieved from https://doi.org/10.1016/j.pulmoe.2020.03.002.

Received: 06.30.2020 / Review 08.15.2020 / Accepted 09.20.2020

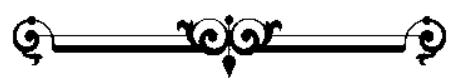

